Copyright (C) 2016 by Academic Publishing House Researcher

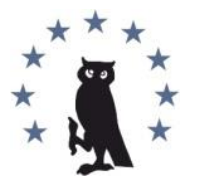

Published in the Russian Federation

European Researcher

Has been issued since 2010.

ISSN 2219-8229

E-ISSN 2224-0136

Vol. 103, Is. 2, pp. 60-68, 2016

DOI: $10.13187 /$ er.2016.103.6o

www.erjournal.ru

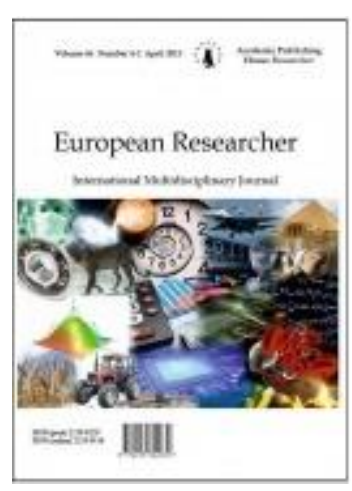

Economic sciences

Экономические науки

UDC 33

\title{
Impact of Advertisement on Malay Young Consumers
}

\author{
${ }^{1}$ Asif Khurshid \\ ${ }^{2}$ Aneel Salman \\ ${ }^{3}$ Nedim Makarevic
}

\begin{abstract}
${ }^{1}$ COMSATS Institute of Information Technology, Pakistan
E-mail: asif.k.mian@gmail.com

${ }^{2}$ COMSATS Institute of Information Technology, Pakistan

E-mail: aneelsalman@yahoo.com

3 Embassy of Bosnia and Herzegovina in Pakistan, Pakistan

E-mail: nmakarevic.science@gmail.com
\end{abstract}

\begin{abstract}
The purpose of writing this paper is to explore the understanding of advertisement and its impact on young consumers. Also it was discussed that how this impact if it is negative can be neutralized. It has been identified after conducting in depth interviews that all respondents were of the opinion that advertisement is a source of communication. In addition to this all respondents are agreed that it has positive as well as negative effects on both children and young adults. Negative impacts can be diluted by advertisers, parents, government and neighbours.

Keywords: advertisement, children, young adults.

\section{Introduction}

Marketers are expected to spend US $\$ 540$ billion globally on advertising this year (CARAT AD SPEND REPORT. SEPTEMBER 2015). The same report highlighted that out of this US \$ 540 billion, $42 \%$ expenditure share is owned by television. This enormous figure shows that television is one of the most widespread medium which is used for spreading word regarding products. Although history of advertising is as old as history of mankind. In many Western societies, the topic of television advertising remained in debate by public and regulatory bodies (Soni \& Vohra 2014). Advertisers target children because of two reasons: firstly, children are children, and are considered separately and secondly, it is because children will become adults (Nowak 1992). So this advertising therefore affects the behaviour no matter this is towards buying or in daily life activities. This behaviour at times become permanent and it lasts from childhood till adulthood. The impressions about products which include goods and services as well as personalities, more often advertisers use celebrities when seen by children as well as young adults through advertisement, the communicated ideas lasts with them for long period of time. Children and
\end{abstract}


young adults memorize the slogans, logos, brand names, colour combinations, songs, jingles, celebrity styles and many more which are shown in advertisements. Even characters like Ronald McDonald which is solely created and promoted for children are also loved by young ones. They cherish and play with these type of characters whenever they visit outlets. This character target the children in promoting brand image or increasing market share of the companies. The dimensions of advertisement which may inspire children are very well explained by Venkatesh (2015). According to him if advertisement depicts children positively only if they are athletes, youngsters are pushed to strive for athletic prowess. If they are portrayed as rebels or as fun-lovers, these images are reinforced. On the other hand, if advertisements portray youthful scholars positively, the advertisements help in developing a favourable image of good students and may assist in motivating them toward education as a goal (Watchravesringkan et al. 2010). So it all depends on advertising agencies that how they advertise their products. According to Chan \& Huang, (2001) that by 7 and 8 years of age, children become aware of the fact that main objective of advertisers is to persuade the customers to purchase the product by sharing the information about a product or company. This creative and attractive persuasion about products is very well understood by children of 7 to 8 years. Despite advertising claims that they are straightforward in nature, the children rejects this stance and they still argue about the truthfulness of advertising campaigns (Manchanda et al. 2003). So the children who are above 7 years are experienced enough to understand and critique the advertising. But on the other hand, it is the opinion of certain researchers that young people and children have deficiencies in processing the information communicated in advertisements like they are incapable to comprehend the objectives of the communicator (Day \& Stafford 1997). Further, it has been shown that children are not readily able to use cognitive defences (Veer et al. 2010). This advertisement can have adverse impact on sociological, attitudinal and behavioural. So most of the times no matter the products whether advertised on print media or electronic media they have an enormous impact on the children and young adults in various dimensions like it may distorts their thinking pattern or it may lead them towards wrongdoings like advertisement by Benson \& Hedges which is a cigarette brand by Pakistan Tobacco Company which is subsidy of British American Tobacco company in which it is shown that smokers have very good social status. This advertisement definitely mislead the youngsters or even teen agers. There are some very thought provoking adds which definitely ignite awareness or severity of situation among children. Like in Pakistan a public service massage was broadcasted in shape of an advertisement in which a child after making drawings of his father, mother, siblings and herself omit a leg and then said that "it is me". And this deficiency is because of Polio. According to researchers advertising is one of the great reasons of children obesity among children. Advertisers promote food items which have excess proportion of fat, sugar and salt (Bublitz \& Peracchio 2015). In order to check this strategy of advertisements of food items, some European countries like United Kingdom and Netherlands has come up with the policies who restrict the amount, nutrition value and marketing strategies of advertisement pertaining to food (Moreira et al. 2015). Even in Australia, regulators have completely ban the food advertising to the children. This ban of food advertisement in Australia and code of conduct for companies promoting food items really worked a lot and checked those companies who exaggerate about their food items. The negative impact of advertisement upon children and young can be reduced rather neutralized by parental communication which can be a very useful tool for moderating TV commercials (Howton et al. 2016). But I think that this comment was valid before 1990s as now world is bombarded with advertisements through television, internet, through mobiles and lot of other mediums. But the dialogue between parents and children regarding different advertisements even during shopping, driving or travelling can eliminate various misunderstandings of children. But this is mandatory that parents should be open for discussion and instead of some short comments they should elaborate the scenarios of various advertisements before according to children mental capacity.

Following are some of the objectives of writing this research paper:

a) To explore the understanding about advertising among young adults.

b) To investigate the impact of advertisement on children and young adults.

c) To study how the impact of advertisement can be neutralized (If it is negative). 


\section{Methodology}

1 Questionnaire

There were total four questions for discussion. The very first question was meant to explore the concept of understanding of advertising by all respondents. Then they were asked about the impact of advertisement upon children. The next question was about how young adults are affected by the advertisement. Then they were asked that if there is any negative impact on children and young adults how this negative impact can be neutralized. And the lastly they were asked that if they want to contribute anything towards this particular topic which is not part of questions asked.

2 Sample and Data Collection

For this particular study I have selected the young adults for in depth interviews. These young adults fall within age bracket of 18-25 years. This age bracket for young adults was defined by (Cardoso \& Pinto 2010). From these eight respondents two were females whereas 6 students were male. All are undergraduate students and were Malay. With their consent interview was recorded vocally as all of them were of the opinion that they will be uncomfortable in answering the questions if video recording is there.

\section{Literature Review}

It is really an interesting experience to study young adults because of the following reason. First of all during recent years children and young adults have often portrayed as competent consumers (Cardoso \& Pinto 2010) In the same paper the author debate on the issue of "Consumer competence". According to the author this consumer competence comes from consumer socialization which can be defined in the following words "it is a processes by which young people acquire skills. Knowledge and attitudes relevant to their functioning as consumers in the market place". So when it is studied that from where this skill, knowledge and attitude can be acquired it is revealed that family who is main source of values and standards for a young adult played a vital role in establishing consumer competence among young adults (Day \& Stafford 1997). (Ragunathan et al. 2015) also identified another three sources for establishing consumer competence among young adults which are peers, media and educational institutions.

\section{Brand and children and Young Adults}

There are researchers who are of the view that brand of certain commodities like computer, clothes, shoes, mobile phone etc. are of great importance for not only young adults but also have great importance for school children. Motwani \& Agarwal (2014) in one of their article has mentioned that advertising, peers, and celebrities/role models have the great potential to contribute to brand choice among children, teens and young adults. All mentioned elements have immense role in selection of brand by mentioned goups. Whereas Wan Edura Wan Rashid along other co- authors in one of Journal Article title "Brand Perceptions among School Children" mentioned that although school children have showed a complex understanding of what brand represents but still they want to own branded goods in their future.

\section{Advertisement and Sales Volume}

Any company can make its brand more competitive and influential if it advertises and projected it correctly. In an article written by Khanna et al. (2013), it is expressed that marketing experts generally agreed with the fact that advertising and brand value has strong relationship. He has also mentioned that correct positioning of brand tied the customers strongly. So it can be inferred that advertising and brand value has direct relationship. The more a company invests in advertising, the brand value will be strengthen accordingly. The mentioned statement can better be exemplified in the pharmaceutical industry where Merck, which is a second largest pharmaceutical company in the world, invested about \$145 million on advertisement of Vioxx which is prescribed for arthritis and joint pain. This investment projected the sales by more than 300 percent and turnover of product touched $\$ 1.5$ billion (Kay 2006)So if investment on product advertisement is augmented the outcome will be nurture the product brand value which will boost the sales and it also contributes towards company value. But this brand choice may leads towards compulsive buying. (Laros \& Steenkamp 2005) define compulsive consumption as "a response to an uncontrollable drive or desire to obtain, use, or experience a feeling, substance, or activity that leads the individual to respectively engage in behaviour that will cause harm to the individual or others". Mentioned buying behaviour is common among young adults (Tirmizi 2009). This 
behaviour is regardless that whether teen agers are shopping under supervision or they are independent during shopping. Whereas (Moore et al. 2015) has mentioned the fact that compulsive buying tendencies have increased tremendously in the last ten years. Under this compulsive buying, people, especially young adults are influenced by advertisements or they may be impressed by the product brand or at times they are trapped by the display of items or this behaviour may be outcome of strong salesmanship of different stores or shops. Once they fascinated then they purchase such items which have no use to them. This habit rather addiction of shopping leads them towards debts. This era can be termed as an age of plastic and virtual money. The growth of credit cards is progressing globally at a rapid pace and people are utilizing these cards without realizing the worth of their purchasing power. Personal loans and leasing along with credit cards enable individuals as well as families to spend more. So availing these facilities means continuous burden on the pocket or more precisely it can be termed as expense for number of months even for years.

3. Role of Materialism

Another belief which is strongly associated with compulsive buying behaviour is materialism. So when people increasingly consume the symbolic meanings associated with goods in expressing their identity and searching for a better self then there spending pattern is misguided by their false belief (Moore et al. 2015). So from the above argument its can be inferred that no matter advertisers present different products in unique ways or financial institutions offer different products like credit cards, personal loans which can lead towards overspending or strong salesmanship shown by people selling different brands or websites offer products impressively people should be well aware of all these marketing tactics. They should spend money and do shopping according to their purchasing power. Purchasing decisions are processes that needed to be learned and practiced (Xie et al. 2015). The art of shopping should be communicated to children so that they can avoid overspending not only in their childhood but also during adulthood. They should equip with the right pattern of saving which can help them in financial crisis or they can finance their education on their own. The use of credit card should closely be monitored by parents or by teachers or any other mentor so effectively that the debt burden may not lead them towards stress.

\section{Result and Discussion}

1 Concept of Advertisement

In the response of very first question which was asked to know their understanding about advertising. Following are some responses regarding advertising:

"Advertising is a way of communication"

Another response was:

"Advertising is to attract customers"

A female respondent carefully defined advertisement as

"Advertising is something through which organizations tell their customers about their products so that they can increase their market share and profitability"

Another student defined the advertisement in the following manner:

"Advertising is something through which company approach consumers and customers and disseminate information about their goods and services."

Under the light of above statements it can be inferred that all students are agreed that Advertising is a mean of communication and the basic purpose is to share the information about the products (goods and services) to increase the market share which lead a company towards increase in profit. Respondents also highlight that organizations use bill boards, television and newspapers for adverting. I am amazed that none of them highlighted that through internet companies also advertise their products. Although all of the students were final year students and most of them were using their Laptops when they were asked for interview. In my opinion may be internet is that mean of advertising through which companies are promoting the image of their products along with the increase in market share of the company. But this important mean which is totally ignored by the student may be companies winning their confidence without realization of their target market. When the advertising is termed as "medium of communication" it sounds like participants are aware of the strength of messages which are communicated through audio, visual and written messages. Most of the times the jingles, songs, slogans or even brand images or brand 
names memorized by audience and whenever they go to market they ask for that particular brand. Even in supermarkets the music or the announcements made again and again through speakers or by the promoter hired by the company repetitively different messages which leave a very strong impression on the buying decision of customers. Even the companies which are producing ice creams, chocolates, biscuits and now even detergents and many more those company are trying hard to involve children in different activities or even small gifts for children who really played vital role in the buying decision of their parents.

The communication definitely tried to be done in unique way so that it left unforgettable impression on the mind of target audience. Apart from it the message should be so catchy and interesting that it should be repeated by the audience/customers who purchase that particular item. The colouring schemes of the packaging, test marketing, and many other techniques all contribute towards advertisement. One of the respondent mentioned that billboards are very good source of advertisement. She mentioned that billboard by Digi near International Islamic University Malaysia is a very good advertisement by the company. She admire the contents of the company written on that board. She was of the opinion that Logo, name and the services rendered by the company is very well summarized in that billboard. She said that yellow colour is highlighted which becomes so prominent that many students wherever they see yellow colour they recall the ad by Digi. She said that this is effective advertisement. So billboards which can be seen along the roads or highways can attract the attention of commuters. This effective medium of advertisement I must say that really contribute a lot towards organizational image and can bring new loyal customers towards organization.

\section{Impact of Advertisement on children}

The second question was about the impact of advertisement upon children. All were agreed that advertisement has both negative and positive impact on children.

All respondents have to think a lot about highlighting a positive impact of advertisement. Conclusively all were agreed that it ignites creativity, awareness about products and great source for children. There was consensus that advertisement through television is a great source of inspiration for children and they learn a lot from those advertisements. But when they asked about the negative impact all said that various products like junk food, carbonated drinks and many other unhealthy products which are major cause of obesity among children. A respondent also discussed advertisements by "Ben 10" in the following words that:

"The advertisement like ben1o lead children towards the world of fantasy and imagination and they always look for some imaginative powers and children may avoid hard work and they may just keep on striving for getting that power which does not exist”

These types of advertisement which are quite imaginative in nature may distort children perception and their thinking pattern. These type of trends are quite common and used in impressive manner by advertisers. Children after watching these advertisements may seek for these imaginative powers and something which is not present in this world of blood and flesh. The respondent was off the opinion that this type of advertisement has long lasting and a great cause of day dreaming among children as they inspired by the characters and the stories elaborated in these advertisement.

Another respondent mentioned that:

"Adultery products or products like body wash when advertised the women or at times the character expose their bodies which show something which is not meant for children."

In this case the products when publicised the content of advertisement totally ignore ethics and Islamic principles. They use human body to win the confidence of the customers but when these advertisements are played during prime time or even during the TV programs for children they definitely get some negative image after watching these kind of advertisements. Another respondent comment about negative image of advertisement in the following words:

"Junk food, carbonated drinks and may other products which are not good for children's health when advertised they ask their parents to get that product which not only disturb the monthly budget of their parent but also a great reason of obesity among children"

Under the light of above comments it can be recognized that colourful packaging, striking displays of products, melodious jingles and many more lead children to purchase that particular 
item. No matter whether it is useful for them or it has some extremely negative impacts they just insist their parents to purchase that product. This leads the society towards over spending and when parents have to purchase something for their descendants which their income do not allow them. It really can be considered as burden on their pockets. In the later part of this question when respondents were asked to exemplify the positive impact of advertisements upon children then the following responses were noted:

"It bring creativity in children"

"It is a great source of information and children may came to know that what new developments by different company are"

The above comments by respondent pointed out the trend or the improvement of children's knowledge. As far as creativity there are some companies who arrange different contests for children and establish winning and fighting spirit among children. Although respondents did not exemplify the positive impact of advertisement but 6 out of 8 were of the opinion that advertisement is a great source of creativity for children. In addition to this they said that public service messages are very well understood by children and they stick to that message whatever they conveyed through that message.

3 Impact of advertisement on Young Adults

In the later part of study when respondents were asked about the impact of advertisement upon young adults. They all were agreed that like children it has negative as well as positive impact upon young adults.

One of the responses was:

"Advertisement is one of the great source of information but it all depends on the person that what type of information he or she is looking for."

Another opinion towards this question was

"Most of the time young adults inspired by the role models and starting copy them. The celebrities who are casted by advertisers most of the time young adults follow them blindly without realizing the fact that whether it is according to Islamic norms and ethics or not."

Advertisements also lead young adults towards materialism. One of the respondent mentioned this in following words:

"Advertisement is one of the great reason of overspending on the products like mobile phones, laptops and on food"

One of the respondent who was female and final year student of BBA. She responded quite comprehensively:

"Since childhood my parents are like my friends. My mother is a nurse and father is working for bank. We watch television together and they keep on discussing about different advertisements and programs which we watch. This attitude of my parents helped me a lot to understand the trends which advertisers and media want to set. In addition to this my mother used to bring lot of literature from hospital. After reading that literature I must say I came across the facts of nutrition value of various products. That literature also told me that what the consequences of taking unhealthy food are. And since childhood this........ I must say that........this proper, timely and continuous helped me to avoid the negative effects of advertisement."

The above response is one of the most comprehensive response which I got. The student told how her parents educate her about the media and the level of interaction enabled her to discuss all thing with her parents. This shrinkage of communication gap not only allow her parents to guide and teach her about media but also she shared her beliefs and ideas openly through which her creativity remained the part of her personality.

As far as positive response of advertisement on young adults is concerned the respondents were of the opinion that:

"Advertisement is a great source of information."

"Through advertisement we came across about different developments of different companies."

"Young adults came across with the various innovations by many Malaysian companies which bring ease to their lives." 
"There are three major ethnicities in Malaysia. Malay, Chinese and Indians. All have their own norms and whenever they are communicated through advertisement that some Malaysian based company invented some new product all people from mentioned ethnicities tried that product according to their purchasing power. This attitude appreciates the inventors and innovators and they keep on trying to bring some thin unique for their countrymen."

After analysing above comments it is quite evident from all comments that advertising is treated as major source of communication. This source of communication is so strong that all inventions and innovations are communicated through this source of advertisement. This communication is so effective that if this source is used effectively then a lot of prosperity can be observed. That advertisement also establish a sense of competition among the companies and they tried hard to bring quality, innovation and improvement in the living standard of people.

4 How negative impact of advertisement can be neutralized?

The last question was that how the negative impact of advertisement can be neutralized. The answers by respondents were really dynamic. One respondent was of the opinion that:

"First of all advertisers should rethink about the company's strategy of promoting goods. Advertisers should follow some ethics and Muslims should abide by the Islamic principles. The content, message and the role of celebrities should be combined in such a approach that it may not contaminate the thinking pattern of children or young adults. Secondly Government should come up with a strong code of conduct for advertisers. Government should keep on regulating the advertisers so they may not use any technique which may have adverse effect on society. The third and foremost role is of parents. The close interaction of parents enable not only children but also young adults to understand the optimal use of money and products."

Another respondent replied this question in the following words:

"In my opinion government should be rigid regarding whatever is displayed rather promoted through advertisement. The celebrities or any other content that is against ethics should be banned and heavy penalties should be imposed. So that this practice can be eliminated. Secondly parents should reduce the communication gap and they should try their level best to educate the children about good and bad things. These children if educated properly than they never the lesson throughout their life and they can easily identified good and bad. Third important role can be played by the teachers who have I think great role in making the personality of student's life. Apart from course they should tried to establish a sense of right and wrong among their students."

Another comment by respondent was:

"Advertisers themselves, Government, parents and neighbours all should tried to reduce the negative effect of advertisement. Advertisers before advertising anything should carefully go through the whole idea and the way it is recorded. Secondly, government should be strict and if through advertisement any company promote nudity, vulgar and bad stuff those advertisers or companies should be banned heavy fines should be imposed. Role of parents can also play an important part in nullify the negatives of advertisement. Through communication and after open discussion it can be reduced. Another important component is neighbours. Neighbours should keep an eye on the children and young adults and if anything they realized which is against the normal routine means if children or young adults tried to exhibit some behaviour which is against ethics or Islamic principles they should discourage them and intimate their parents."

This respondent has highlighted the four groups which are advertisers, government, parents and neighbours who can dilute the negative impact of advertisement. He added the role of neighbour as this respondent belong to rural part of Malaysia where according to his opinion neighbours own all the children and if there is anything against morals they guide the children. This attitude really make the environment more conducive for all income groups. The above comments highlighted four groups who can defuse or neutralize the negative impact of advertising. These four groups are advertisers, government, parents and government. Advertisers, themselves audit their work. They should not use any technique which is against moral values or Islamic ideology. As Malaysia is a Muslim country so Islam should be main source of knowledge and all actions. No matter the advertisers are Chinese, Hindus or any other religion they should follow 
fundamental principles of ethics and should not portray anything which is below moral standards. No matter whether they are advertising Body Wash, Lotions, Home Appliances, FMCGs some ethics should be followed through those advertisements. Secondly, government should be very careful whatever is advertised by companies. All respondents were of the opinion that government should come up with Code of Conduct and it should ensure its implementation. Government should keep an eagle eye on the advertisements so that nothing against ethics can be broadcasted. Heavy fines and bans should be imposed so that the competitors learn to compete within ethical surroundings. Third important social group which can play its role is parents. All respondents were agreed that open and frequent communication with parents help the children and young adult to differentiate between good and bad. Communication Gap if reduced rather eliminated between parents and children than a healthy social can prevail. Issues like overspending, smoking, blind copy of celebrities can be overcome very easily. Simultaneously working parents should give ample time to their children so that children may not remain deprived and the communication between parents and children can play its role in brought up of children. Another important pillar identify by one of the respondent is neighbours. Neighbours should keep an eye on the children and young adults living in the vicinity so if there is anything which is against social and ethical norms that should be discouraged and should be shared with the parents.

\section{Conclusion}

It is concluded that advertisement is considered as a good source of communication and all respondents agreed that through advertisement companies attract customers. Apart from it all are agreed that advertisement has both negative and positive impact. Negative impact results in overspending, obesity or may lead towards disturbing thinking pattern after watching nudity or any other unethical message. As far as positive impact is considered it is revealed that it brings creativity among children and a source of information among young adults. For negative impact respondents were of the opinion that it is neutralized by communication with parents and guidance by teachers. Whereas respondents were of the opinion that advertisers should be vigilant and should follow some moral and ethical standards. Last all respondents said that Government should come up with some comprehensive code of conduct for advertisers and it should also ensure its application. Simultaneously they were of the opinion that heavy penalty should be imposed for violating that code of conduct.

\section{References:}

1. Bublitz, M.G. \& Peracchio, L.A., 2015. Applying industry practices to promote healthy foods : An exploration of positive marketing outcomes. Journal of Business Research.

2. Cardoso, P.R. \& Pinto, S.C., 2010. Hedonic and utilitarian shopping motivations among Portuguese young adult consumers. International Journal of Retail \& Distribution Management, $38(7)$, pp.538-558.

3. Chan, A.K.K. \& Huang, Y.-Y., 2001. Chinese brand naming: a linguistic analysis of the brands of ten product categories. Journal of Product \& Brand Management, 10(2), pp.103-119.

4. Day, E. \& Stafford, M.R., 1997. Age-related cues in retail services advertising: Their effects on younger consumers. Journal of Retailing, 73(2), pp.211-233.

5. Howton, J. et al., 2016. A comparison of food safety programs using the Customizable Tool for Online Training Evaluation. Food Control, 59, pp. 82-87. Available at: http://linkinghub.elsevier.com/retrieve/pii/So956713515002613.

6. Kay, M.J., 2006. Strong brands and corporate brands. European Journal of Marketing, 40(7/8), pp.742-760.

7. Khanna, C., J. M. van der Voordt, T. \& W. Koppels, P., 2013. Corporate real estate mirrors brand: a conceptual framework and practical applications. Journal of Corporate Real Estate, 15(3/4), pp.213-230.

8. Laros, F.J.M. \& Steenkamp, J.B.E.M., 2005. Emotions in consumer behavior: A hierarchical approach. Journal of Business Research, 58(10), pp.1437-1445.

9. Manchanda, P. et al., 2003. Banner Advertising as a Customer Retention Tool in Customer Relationship Management. Working Paper, Department of Marketing, University of Chicago. 
10. Moore, D.J. et al., 2015. Affect Response Intensity: to An Individual Difference Advertising Appeals. , 22(2), pp.154-164.

11. Moreira, C.C., Moreira, E.A.M. \& Fiates, G.M.R., 2015. Perceived Purchase of Healthy Foods Is Associated With Regular Consumption of Fruits and Vegetables. Journal of Nutrition Education and Behavior, 47(3), pp.248-252.e1.

12. Motwani, D. \& Agarwal, K., 2014. IMPACT OF FEAR APPEAL IN ADVERTISEMENT ON Introduction : Literature Review : International Journal of Management And Commerce, 1(3), pp.50-58.

13. N, V.M.S., 2015. Munich Personal RePeC Archive., (63978).

14. Nowak, G.J., 1992. TV Viewer Characteristics and “ Results Beyond Response .” Journal of Direct Marketing, 6(2), pp.18-31.

15. ed on Consumer Behaviour. Procedia Computer Science, 50, pp.329-334.

16. Soni, P. \& Vohra, J., 2014. Advertising foods to Indian children: what is the appeal? Young Consumers, 15(2), pp.178-192.

17. Tirmizi, M.A., 2009. An Empirical Study of Consumer Impulse Buying Behavior in Local Markets. European Journal of Scientific Research, 28(4), pp.522-532. Available at: http://www.scopus.com/inward/record.url?eid=2-s2.0-

64949137881\&partnerID $=40 \&$ md $5=43 a 3 f 8 f 5 b 8013 a a 5$ cd 9398760315 efeb.

18. Veer, E., Becirovic, I. \& Martin, B. a S., 2010. If Kate voted Conservative, would you? The role of celebrity endorsements in political party advertising. Available at: http://dx.doi.org/10.1108/03090561011020516.

19. Watchravesringkan, K., Hodges, N.N. \& Kim, Y.-H., 2010. Exploring consumers' adoption of highly technological fashion products: The role of extrinsic and intrinsic motivational factors. Journal of Fashion Marketing and Management, 14(2), pp.263-281. Available at: http://dx.doi.org/10.1108/13612021011046101.

20. Xie, F.T. et al., 2015. Emotional Appeal and Incentive Offering in Banner Advertisements EMOTIONAL APPEAL AND INCENTIVE OFFERING IN BANNER. , 2019 (September), pp.29-37.

УДК 33

\title{
Влияние рекламы на малайских молодых потребителей
}

\author{
${ }^{1}$ Асиф Кхуршид \\ 2 Аниль Салман \\ 3 Недим Макаревич
}

\begin{abstract}
${ }^{1}$ КОМСАТС Институт Информационных Технологий, Исламабад, Пакистан E-mail: asif.k.mian@gmail.com ${ }^{2}$ КОМСАТС Институт Информационных Технологий, Исламабад, Пакистан E-mail: aneelsalman@yahoo.com 3 Посольство Боснии и Герцеговины в Пакистане, Пакистан E-mail: nmakarevic.science@gmail.com
\end{abstract}

Аннотация. Целью написания данной работы является проведение исследования понимания рекламы и ее влияния на молодых потребителей. Обсуждаются механизмы такого влияния, если оно отрицательное, как может быть нейтрализовано. Было обнаружено после проведения ряда интервью, что все респонденты высказали мнение, что реклама - это источник общения. В дополнение к этому все респонденты согласились с тем, что она имеет как положительное, так и отрицательное воздействие на детей и молодых людей. Негативные последствия могут быть разбавлены рекламодателями, родителями, государством и соседями.

Ключевые слова: реклама, дети, молодые люди. 